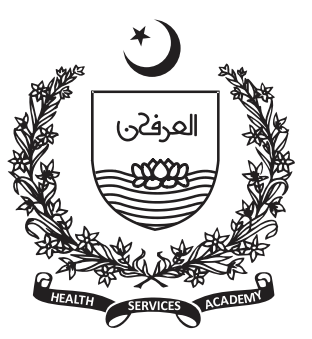

1Junior Laboratory

Technologist

(Microbiology)

Department of

Microbiology, Pakistan

Kidney and Liver Institute

\& Research Center, Lahore,

Pakistan (PKLI \& RC).

2Laboratory Technologist

(Microbiology)

Department of

Microbiology, Pakistan

Kidney and Liver Institute

$\&$ Research Center, Lahore, Pakistan (PKLI \& RC).

${ }^{3}$ Assistant Manager

(Microbiology)

Department of

Microbiology, Pakistan

Kidney and Liver Institute

\& Research Center, Lahore,

Pakistan (PKLI \& RC).

${ }^{4}$ Head of Department

Department of

Microbiology, Pakistan

Kidney and Liver Institute

\& Research Center, Lahore,

Pakistan (PKLI \& RC).

Corresponding Author:

Altaf Ahmed

Email:

azka.rizvi528@gmail.com

\section{A Cross Sectional Study to Evaluate Awareness About Hepatitis A \& E Among Students in Lahore}

\author{
Azka Rizvi ${ }^{1}$, Naveed Ahmed ${ }^{2}$, Ayesha Naeem ${ }^{1}$, Waqas Saleem ${ }^{3}$, Muhammad \\ Ilyas ${ }^{1}$, Altaf Ahmed ${ }^{4}$
}

\begin{abstract}
Background: The aim and objectives of the study were to determine the knowledge, attitude and practices among biological and non-biological students regarding Hepatitis A virus (HAV) and Hepatitis E virus (HEV).

Methods: The present study was conducted by the Department of Microbiology, Pakistan kidney \& liver institute and research center (PKLI \& RC) at University of Veterinary and Animal Sciences (UVAS), Lahore, Pakistan. The study was conducted in November, 2019 to January, 2020. A total of 326 respondents (students) participated in the present study. Respondents filled a pre-tested structured questionnaire. The variables accessed were knowledge of the diseases including etiology, mode of transmission, and prevention and control measures.
\end{abstract}

Results: Most $81.56 \%$ of respondents from biological sciences (B-S) group and $51.70 \%$ from non-biological sciences (N-B-S) had awareness about HAV/HEV. Furthermore, $72.06 \%$ of respondents from BS group and $13.60 \%$ of respondents from NBS group had knowledge about the mode of transmission and spread of HAV and HEV infection. Only $16.20 \%$ of students from B-S group were aware about importance of vaccination against HAV/HEV. While a very low prevalence was found about vaccination in N-B-S group that is only $4.76 \%$.

Conclusion: The study shows significance difference in the awareness level among students from biological sciences and non-biological sciences background. Respondents were found to misunderstand the hepatitis $A$ \& $E$ infections with hepatitis B \& C, which suggests that there is need to spread awareness about the differences in their spread and severity of these infections. Awareness campaigns should be conducted to make people aware of the ways HAV/HEV spreads, its mode of transmission, severity of infection and preventive measures to minimize its spread as well as chances to acquire HAV/HEV infections.

Keywords: Hepatitis A, hepatitis E, knowledge; attitude, practices

\section{Introduction}

$\mathrm{V}$

iral hepatitis is responsible for causing significant morbidity and mortality every year throughout the world. While it remains selflimiting most of the time but unrecognized and under treated viral hepatitis can lead to chronic hepatitis, cirrhosis, hepatocellular carcinoma, liver failure and even death in immune-compromised (1). Hepatitis A (HAV) and Hepatitis E virus (HEV) are responsible for causing acute viral hepatitis (2). In the past two decades, focus on eliminating hepatitis $B$ and 
hepatitis $C$ lead to negligence towards occurrence of HAV and HEV infections. However, the fact that HAV infects 1.4 billion people and HEV infects 20 million people each year resulting in 56000 deaths respectively, requires immediate attention (3).

Asymptomatic infection of HAV occurs in children while on the other hand in case of adults and older children there is a wide spectrum of disease ranging from mild to anicteric to fulminant hepatic failure which results in the wild range of morbidity and mortality (4). Though it remains endemic in developing countries like Pakistan but the rate of seroprevelance is decreasing day by day in developed countries. Both HAV and HEV are transmitted through fecal-oral route (5). HAV spreads through eating and drinking raw and contaminated food while HEV infection is mostly associated with contaminated drinking water and poor sanitation conditions (6).

The virus responsible for causing hepatitis $\mathrm{A}$ is a remarkably resistant positive sense, non-enveloped RNA virus belonging to family Picornaviridae in the genus Hepatovirus (3). It has 6 genotypes out of which I, II, and III have been identified as human pathogen (7). In third world countries like Pakistan, because of poor sanitary conditions, there is a continuous increase in HAV infection cases and almost 90\% population become infected with the virus during their early childhood. During early childhood there is no or almost very minimum signs of clinical infection and the person develop the lifelong immunity making them immune for the lifetime (8). However, in middle income, economically stable areas where sanitary condition is much more developed, children might escape infection in childhood leading to accumulation of older people who were never exposed to the virus. In case of developed countries, the spread of virus is minimum to none and people only get infected by travelling to disease endemic areas or being exposed to the infected individuals (9). However, people do get infected in industrialized countries by consuming contaminated produce such as tomatoes and berries etc (10). There is no specific treatment for HAV infection and infection can last from few weeks to several months but live attenuated vaccine is available in China. This vaccine has protective effects even after administration of only one dose, 2-weeks post exposure to the virus $(2,11)$.

Like HAV, HEV is a positive sense non-enveloped RNA virus belonging to the family Hepeviridae in the genus Hepevirus. HEV is the main cause of acute liver failure (ALF) or also called as acute hepatitis. HEV is the most common cause of acute viral hepatitis throughout the world. During an outbreak in the early 1980s, it was discovered in Indian occupied province of Kashmir, when a patient was tested negative for both HAV and HAB. It was called hepatitis " $E$ " virus because of its affiliation with epidemics and enteric mode of transmission (12). HEV has only four genotypes. Genotypes 1 and 2 infects humans only, but genotypes 3 and 4 infect humans along with pigs and many other mammalian species (1). HEV is endemic in many countries of Asia, Africa, Middle East and Central America (6). In developed areas with better sanitation, people rarely get infected and genotype-3 is mostly responsible for the infection because of ingesting raw or undercooked meat of infected animals. In rare cases, HEV infection can get worse and lead to acute live failure or fulminant hepatitis. Which occurs more frequently in pregnant women and out of those women in the second or third trimester, are at greater risk of developing acute liver failure leading to fetal loss and even death. Death of up to $20-25 \%$ of pregnant women can occur if they get infected with hepatitis E in third trimester, as they are more prone to getting infected (13). There still isn't any specific treatment available for HEV but hospitalization is required for people with fulminant hepatitis. Also, ribavirin is proved to be a success in treating immunocompromised patients with chronic hepatitis. In 2011, China made sub-unit vaccine to prevent $\mathrm{HEV}$, made it to the private market but it has not yet been approved in other countries. The vaccine has proved to provide long term immunization for up to 4.5 years (14).

Geographical location of Pakistan suggests that there are chances of occurrence of HEV and HAV infections with non-Pakistani origin i.e. from other Asian countries. Although, about $90 \%$ of population becomes infected with these viruses even before reaching the age of 10 years and they remain immune to the infection for the rest of their lives $(15,16)$. Last year, several cases of hepatitis $\mathrm{E}$ have been reported in different districts and cities of Punjab, Pakistan. On April $26^{\text {th }}, 2019$, it was reported by the local news channel that (8).

Previous studies showed that the incidence of HAV and HEV was more in under-developed areas with poor sanitation and low socio-economic status as compared to areas with developed and more educated population inhabiting it $(17,18)$. So, present study was 
designed to evaluate the prevalence and relative awareness of population with biological science background and population with non-biological sciences background. Aim of the study was to better understand the impact and role of education system and awareness campaigns among biological sciences and non-biological sciences students. So that better campaigns can be conducted to raise awareness regarding hepatitis $\mathrm{A}$ and $\mathrm{E}$ in order to help decrease its incidence.

\section{Methodology}

\section{Study design}

The present cross-sectional survey study was conducted by the Department of Microbiology, Pakistan kidney \& liver institute and research center (PKLI \& RC) at University of Veterinary and Animal Sciences (UVAS), Lahore, Pakistan. The study was conducted in November, 2019 to January, 2020. A questionnaire consisting of 18 multiple-choice questions. It was designed to evaluate respondents' perception and understanding about hepatitis A (HAV) and hepatitis E (HEV) infection. The questionnaire was divided into three parts. The first section addressed demographics which included: age, gender, marital status, educational level. Second part included basic knowledge about HAV and HEV including its mode of transmission, health status of the respondents, family history of HAV or HEV infections, including their practices towards HAV \& HEV screening and vaccination. The respondents were requested to recall whether they had HAV or HEV testing, the results of the blood test, and whether they had received HAV or HEV vaccination. The questionnaire was developed in English. In this study, students from science and non-science departments, healthcare professionals (DVM) categorizing them into biological sciences (B-S) and non-biological sciences (N-B-S) groups. Biological science includes students from, Department of Food, Nutrition \& Dietetics, Department of Biotechnology \& Genetic Engineering, Department of Microbiology. Department of Medical Laboratory Sciences and Faculty of Veterinary Sciences. While, students from Non-Biological sciences includes students from UVAS Business School (UBS).
Table 1. Frequency distribution of socio demographic variables of study participants $(n=326)$.

\begin{tabular}{|c|c|c|c|}
\hline Variables & Description & $\begin{array}{c}\text { Number of } \\
\text { Participants }\end{array}$ & $\%$ \\
\hline \multirow{4}{*}{ Age } & $<18$ & 76 & 23.31 \\
\cline { 2 - 4 } & $18-25$ & 233 & 71.47 \\
\cline { 2 - 4 } & $26-35$ & 12 & 3.68 \\
\cline { 2 - 4 } & $36-45$ & 5 & 1.53 \\
\hline \multirow{2}{*}{ Gender } & Male & 133 & 40.79 \\
\cline { 2 - 4 } Marital status & Female & 193 & 59.20 \\
\cline { 2 - 4 } & Single & 294 & 90.18 \\
\hline \multirow{3}{*}{ Education } & Married & 32 & 9.81 \\
\cline { 2 - 4 } & Graduation & 249 & 76.38 \\
\hline \multirow{3}{*}{ Departments } & $\begin{array}{c}\text { Post- } \\
\text { Graduation }\end{array}$ & 77 & 23.61 \\
\cline { 2 - 4 } & $\begin{array}{c}\text { Biological } \\
\text { sciences }\end{array}$ & 179 & 54.90 \\
\cline { 2 - 4 } & $\begin{array}{c}\text { Non-Biological } \\
\text { sciences }\end{array}$ & 147 & 45.09 \\
\hline
\end{tabular}

\section{Data collection}

Questionnaires were distributed among personnel who were volunteered to participate in the study. An informed consent was taken prior to collect the data. Data was collected from a total of 326 respondents. Throughout this process, close physical monitoring was done to ensure the quality of data and to omit any discrepancies. Respondents were requested to answer all the question with the best of their knowledge and understanding. After the collection of data, the data was put in Microsoft Excel file and analyzed further for statistical analysis.

\section{Results}

\section{Awareness about HAV and HEV infections}

$81.56 \%$ of Biological Science students and $51.70 \%$ of Non-Biological Science students had knowledge about HAV and HEV infections. Furthermore, $48 \%$ of B-S group said that they know about HAV/HEV infection through reading a research article, 25\% through television and $8 \%$ through reading newspaper. On the other hand, $33 \%$ of N-B-S group learned about these infections through television, $21 \%$ through newspaper and $17 \%$ through research article. 
Awareness about spread and transmission of HAV and HEV infection

$72.06 \%$ of respondents from B-S group and $13.60 \%$ of respondents from N-B-S group had knowledge about the mode of transmission and spread of HAV and HEV infection.

Awareness about personal hygiene

Around $90-95 \%$ of the respondents from both groups were clear that improved personal hygiene, washing hands before and after eating, and drinking filtered/boiled water prevents from acquiring $\mathrm{HAV} / \mathrm{HEV}$ infection.

Awareness about use of antibiotics

When asked if antibiotics can be used to treat HAV/HEV infection, 59.21\% of respondents from B-S group said "No" which means rest of the $41 \%$ of respondents believe that in viral infection, antibiotics can be used. While in N-B-S group $63 \%$ of respondents' response was in favor of using antibiotics in $\mathrm{HAV} / \mathrm{HEV}$ infections and only $38 \%$ of them said that antibiotics cannot be used in $\mathrm{HAV} / \mathrm{HEV}$ infections.

Table 2. Vaccination status of study respondents.

\begin{tabular}{|c|c|c|c|c|}
\hline \multirow{2}{*}{\multicolumn{3}{|c|}{$\begin{array}{l}\text { VACCINATION STATUS OF STUDY } \\
\text { PARTICIPANTS }\end{array}$}} & \multicolumn{2}{|c|}{ Answers } \\
\hline & & & YES & NO \\
\hline \multirow{4}{*}{$\begin{array}{l}\text { BIOLOGICAL } \\
\text { SCIENCE } \\
\text { STUDENTS }\end{array}$} & \multirow{2}{*}{$\begin{array}{c}\text { Vaccination } \\
\text { against } \\
\text { Hepatitis A }\end{array}$} & FREQUENCY & 41 & 138 \\
\hline & & PERCENTAGE & 22.90 & 77.09 \\
\hline & \multirow{2}{*}{$\begin{array}{c}\text { Vaccination } \\
\text { against } \\
\text { Hepatitis E }\end{array}$} & FREQUENCY & 47 & 132 \\
\hline & & PERCENTAGE & 26.25 & 73.74 \\
\hline \multicolumn{3}{|c|}{ TOTAL } & \multicolumn{2}{|c|}{179} \\
\hline \multirow{4}{*}{$\begin{array}{c}\text { NON- } \\
\text { BIOLOGICAL } \\
\text { SCIENCE } \\
\text { STUDENTS }\end{array}$} & \multirow{2}{*}{$\begin{array}{c}\text { Vaccination } \\
\text { against } \\
\text { Hepatitis A }\end{array}$} & FREQUENCY & 28 & 119 \\
\hline & & PERCENTAGE & 19.04 & 80.95 \\
\hline & \multirow{2}{*}{$\begin{array}{c}\text { Vaccination } \\
\text { against } \\
\text { Hepatitis E }\end{array}$} & FREQUENCY & 26 & 121 \\
\hline & & PERCENTAGE & 17.68 & 82.31 \\
\hline \multicolumn{3}{|c|}{ TOTAL } & \multicolumn{2}{|c|}{147} \\
\hline
\end{tabular}

Vaccination status of study participants

When inquired about the vaccination (HAV and HEV) status, it was revealed that from B-S group only $22.90 \%$ of respondents were vaccinated against HAV. While, $77 \%$ of respondents were not vaccinated against HAV. $26.25 \%$ of respondents from B-S group were found vaccinated against HEV, while the other $73.74 \%$ were not vaccinated yet.

In Non-Biological science group, the vaccination status of respondents against HAV and HEV was $19.04 \%$ and $17.68 \%$ respectively.

\section{Blood Testing}

When asked if they have had a blood test for HAV and HEV. Only $36.87 \%$ of respondents from B-S group and $27.89 \%$ of N-B-S group responded said that they have got tested for HAV blood tests previously. 63\% of respondents from B-S group and $72 \%$ from N-B-S group said that they never got tested for HAV.

A very low practices for HEV blood test was found in both group that is; $11.73 \%$ participants from B-S group and $11.56 \%$ from N-B-S group. $88 \%$ of respondents from both B-S and N-B-S group said that they never got tested for HEV.

Table 3. Laboratory testing statuses for HAV and HEV among study participants.

\begin{tabular}{|c|c|c|c|c|}
\hline \multirow{2}{*}{\multicolumn{3}{|c|}{$\begin{array}{c}\text { LABORATORY TESTING STATUS OF } \\
\text { STUDY PARTICIPANTS }\end{array}$}} & \multicolumn{2}{|c|}{ Answers } \\
\hline & & & YES & NO \\
\hline \multirow{4}{*}{$\begin{array}{l}\text { BIOLOGICAL } \\
\text { SCIENCE } \\
\text { STUDENTS }\end{array}$} & \multirow{2}{*}{$\begin{array}{c}\text { Testing } \\
\text { for } \\
\text { Hepatitis } \\
\text { A }\end{array}$} & FREQUENCY & 66 & 113 \\
\hline & & PERCENTAGE & 36.87 & 63.12 \\
\hline & \multirow{2}{*}{$\begin{array}{c}\text { Testing } \\
\text { for } \\
\text { Hepatitis } \\
\text { E }\end{array}$} & FREQUENCY & 21 & 158 \\
\hline & & PERCENTAGE & 11.73 & 88.26 \\
\hline \multicolumn{3}{|c|}{ TOTAL } & \multicolumn{2}{|c|}{179} \\
\hline \multirow{4}{*}{$\begin{array}{c}\text { NON- } \\
\text { BIOLOGICAL } \\
\text { SCIENCE } \\
\text { STUDENTS }\end{array}$} & \multirow{2}{*}{$\begin{array}{c}\text { Testing } \\
\text { for } \\
\text { Hepatitis } \\
\text { A }\end{array}$} & FREQUENCY & 41 & 106 \\
\hline & & PERCENTAGE & 27.89 & 72.10 \\
\hline & \multirow{2}{*}{$\begin{array}{c}\text { Testing } \\
\text { for } \\
\text { Hepatitis } \\
\text { E } \\
\end{array}$} & FREQUENCY & 17 & 130 \\
\hline & & PERCENTAGE & 11.56 & 88.43 \\
\hline \multicolumn{3}{|c|}{ TOTAL } & \multicolumn{2}{|c|}{147} \\
\hline
\end{tabular}

Awareness about severity of infection-to cause liver failure

When inquired about the fact that (HAV and HEV) cause liver failure, it was revealed that only $46.36 \%$ of respondents from B-S group and $32.65 \%$ of N-B-S group were aware of the fact that HAV and HEV cause hepatic failure. While, on the other hand, $54 \%$ of respondents from B-S group and $68 \%$ of N-B-S group were uncertain about the liver failure caused by HAV and HEV.

Table 4. Percentage distributions of HAV/HEV awareness amongst respondents.

\begin{tabular}{|c|c|c|c|}
\hline \multicolumn{2}{|c|}{ Statements of Awareness } & $\begin{array}{c}\text { Biological } \\
\text { Sciences } \\
\text { Students }\end{array}$ & $\begin{array}{c}\text { Non- } \\
\text { Biological } \\
\text { Sciences } \\
\text { Students }\end{array}$ \\
\hline Awareness & FREQUENCY & 146 & 76 \\
\hline
\end{tabular}




\begin{tabular}{|c|c|c|c|}
\hline \multirow{2}{*}{$\begin{array}{c}\text { about HAV } \\
\text { and HEV }\end{array}$} & PERCENTAGE & 81.56 & 51.70 \\
\hline & $\begin{array}{c}\text { Level of } \\
\text { Knowledge }\end{array}$ & $\begin{array}{c}\text { Moderate } \\
* *\end{array}$ & $\underset{* *}{\text { Moderate }}$ \\
\hline \multirow{3}{*}{$\begin{array}{c}\text { Awareness } \\
\text { about } \\
\text { transmission } \\
\text { of HAV and } \\
\text { HEV }\end{array}$} & FREQUENCY & 129 & 20 \\
\hline & PERCENTAGE & 72.06 & 13.60 \\
\hline & $\begin{array}{c}\text { Level of } \\
\text { Knowledge }\end{array}$ & $\begin{array}{c}\text { Moderate } \\
* *\end{array}$ & $\begin{array}{c}\text { Inadequate } \\
*\end{array}$ \\
\hline \multirow{3}{*}{$\begin{array}{c}\text { Awareness } \\
\text { about } \\
\text { personal } \\
\text { hygiene }\end{array}$} & FREQUENCY & 169 & 134 \\
\hline & PERCENTAGE & 94.41 & 91.15 \\
\hline & $\begin{array}{c}\text { Level of } \\
\text { Knowledge }\end{array}$ & $\begin{array}{c}\text { Adequate } \\
\text { knowledge } \\
* * *\end{array}$ & $\begin{array}{c}\text { Adequate } \\
\text { knowledge } \\
* * *\end{array}$ \\
\hline \multirow{3}{*}{$\begin{array}{l}\text { Awareness } \\
\text { about use of } \\
\text { antibiotics }\end{array}$} & FREQUENCY & 106 & 41 \\
\hline & PERCENTAGE & 59.21 & 27.89 \\
\hline & $\begin{array}{c}\text { Level of } \\
\text { Knowledge }\end{array}$ & $\begin{array}{c}\text { Moderate } \\
* * \\
\end{array}$ & $\begin{array}{c}\text { Inadequate } \\
* \\
\end{array}$ \\
\hline \multirow{3}{*}{$\begin{array}{l}\text { Awareness } \\
\text { about } \\
\text { importance of } \\
\text { vaccination }\end{array}$} & FREQUENCY & 29 & 07 \\
\hline & PERCENTAGE & 16.20 & 4.76 \\
\hline & $\begin{array}{c}\text { Level of } \\
\text { Knowledge }\end{array}$ & $\begin{array}{c}\text { Inadequate } \\
*\end{array}$ & $\begin{array}{c}\text { Inadequate } \\
*\end{array}$ \\
\hline \multirow{3}{*}{$\begin{array}{l}\text { Awareness } \\
\text { about } \\
\text { importance of } \\
\text { getting tested }\end{array}$} & FREQUENCY & 58 & 26 \\
\hline & PERCENTAGE & 32.40 & 17.68 \\
\hline & $\begin{array}{c}\text { Level of } \\
\text { Knowledge }\end{array}$ & $\begin{array}{c}\text { Inadequate } \\
*\end{array}$ & $\begin{array}{c}\text { Inadequate } \\
*\end{array}$ \\
\hline \multirow{3}{*}{$\begin{array}{c}\text { Awareness } \\
\text { about severity } \\
\text { of infection-to } \\
\text { cause liver } \\
\text { failure }\end{array}$} & FREQUENCY & 83 & 48 \\
\hline & PERCENTAGE & 46.36 & 32.65 \\
\hline & $\begin{array}{c}\text { Level of } \\
\text { Knowledge }\end{array}$ & $\begin{array}{c}\text { Inadequate } \\
*\end{array}$ & $\begin{array}{c}\text { Inadequate } \\
*\end{array}$ \\
\hline
\end{tabular}

* Inadequate knowledge when correct response was by less than $50 \%$ of the study participants to a particular question. ** Moderate knowledge when correct response for a particular question was by $50 \%$ $80 \%$ of the study participants. *** Adequate knowledge when more than $80 \%$ participants responded correctly to a particular question.

\section{Discussion}

Around $90 \%$ of population of Pakistan is infected with HAV before the age of 10 years due to poor sanitary conditions $(15,19,20) .50-60 \%$ of cases of acute viral hepatitis are reported in pediatric population of Pakistan (12). and only 5.1 to $6.4 \%$ of adults are diagnosed with HAV. By the age of 5 , almost $96 \%$ of Pakistani population is exposed to HAV while 98$100 \%$ of adult population becomes exposed to HAV. Hepatitis E virus (HEV) is the causative agent of hepatitis E, and is endemic in Pakistan and it transmitted through fecal oral route. It occurs mostly during the rainy season when there are high chances of floods and there is mixing of drinking water with sewage water and people have communal life style (12). Knowledge and understanding about HAV/HEV is critical for general public of Pakistan because of increasing number of incidents (21).

Among viral hepatitis, acute viral hepatitis caused by HAV and HEV are at the top in Pakistan with HAV accounting for up to $50-60 \%$ of all the cases, in children (12). While HEV remains endemic in Pakistan affecting younger kids and adult population (5). Pakistan is an under-developed country with health and literacy rate at the bottom of the mark. As hepatitis has become a serious problem of Pakistan (8), there is a need to run awareness campaigns to minimize the incidence of HAV and HEV.

In the present study it was observed that at about $81.56 \%$ of the students from biological sciences group had heard about HAV/HEV infections while $72.06 \%$ of them had knowledge about its mode of transmission. $51.70 \%$ of students from non-biological sciences group heard about HAV/HEV infection and only $13.60 \%$ of them knew how these infections transmit. These results similar to the results obtained from the research done in 2016 to evaluate the level of awareness level among dental students and general public (22). Similarly, a study conducted among dental students and general public regarding hepatitis B awareness in 2011, also reported the difference in awareness level of general population (including people from non-biological sciences background) and dental students as dental students were comparatively more aware than the general population. This might be due to the field related awareness programs, educational sessions, seminars and other field related requirements which made dental students aware of the hepatitis B infection (22). This finding also highlights the need to conduct more campaigns and awareness sessions for not just people from biological and medical sciences but general public as well.

Students were found to take hepatitis A \& E for hepatitis B \& C and were unable to clearly identify their mode of transmission, severity of infection and consequences of not considering it as a serious health problem. Similar case of inability to recognize and differentiate between hepatitis B and A was reported in a study conducted in Hong Kong back in 2010 (23). The study shows significance difference in the awareness level among people from biological sciences and non-biological sciences background. 
People were found to mistake spread of hepatitis A \& E infections with hepatitis B \& C, which suggests that there is need to spread awareness about the differences in their spread and severity of these infections. These results were similar to the survey conducted in Hong Kong about awareness of hepatitis $\mathrm{B}$ infection in public where people found to mistake hepatitis B for hepatitis A (23).

Similar to low awareness about the spread of HBV/HCV infections (23), Covid-19 (24) there is need to educate people about $\mathrm{HAV} / \mathrm{HEV}$ as well. Although only $20 \%$ of B-S group had a family history of $\mathrm{HAV} / \mathrm{HEV}, 22.90 \%$ of them had vaccination against it HAV and 26.25 had vaccination against HEV. But the trend is different in N-B-S group as only $19.04 \%$ of them had vaccination against HAV and 17.68 were vaccinated against HEV, while $28 \%$ of them had family history of the infection. This shows that people from biological science background were more aware of the fact that they should be vaccinated to prevent this disease. Overall knowledge about these infections of both groups was sufficient, but the knowledge about the risk factors was very low.

Almost $70 \%$ of the respondents from both groups were unware of the fact that screening of these infections is critical in preventing the disease as only $11.73 \%$ from B-S and $11.56 \%$ from N-B-S group got tested for HAV, while in HAV the testing rate was $36.87 \%$ and $27.89 \%$ respectively. However, $68 \%$ from B-S and $42 \%$ from NB-S group were aware of the fact that $\mathrm{HAV} / \mathrm{HEV}$ can cause liver failure as well. Screening and vaccination behaviors are interlinked and are associated with respondents' educational level and occupation as demonstrated in awareness survey conducted in Hong Kong (23).

\section{Study Limitations}

For our study design we used small number of students belonging to one institute only, in contrast to more students studying at different institutes in order to generalize the results. This was a single institute based study; therefore, the results cannot be generalized.

\section{Conclusion}

This survey highlights the need to spread awareness among students of Pakistan about HAV/HEV infection. Awareness campaigns should be conducted to make people aware of the ways $\mathrm{HAV} / \mathrm{HEV}$ spreads, its mode of transmission, severity of infection and preventive measures to minimize its spread as well as chances to acquire $\mathrm{HAV} / \mathrm{HEV}$ infections. It is important to understand the need to educate people, especially from lower socio-economic status as they might not know about these infections and how its spreads.

\section{Acknowledgments}

We thank Dr. Muhammad Atique and Ms. Afia Ilyas for their assistance in preparing the questionnaire and research proposal. The content is solely responsibility of the authors.

\section{Conflict of Interest}

The authors have no conflict of interest with any of the research work done by other colleagues/authors.

\section{References}

1. Mohsen W, Levy MT. Hepatitis A to E: what's new? Internal Medicine Journal. 2017;47(4):380-9.

2. Ren X, Wu P, Wang L, Geng M, Zeng L, Zhang J, et al. Changing epidemiology of hepatitis A and hepatitis $\mathrm{E}$ viruses in China, 1990-2014. Emerging infectious diseases. 2017;23(2):276.

3. Sa-nguanmoo $P$, Posuwan $N$, Vichaiwattana $P$, Wutthiratkowit N, Owatanapanich S, Wasitthankasem $\mathrm{R}$, et al. Swine is a possible source of hepatitis $\mathrm{E}$ virus infection by comparative study of hepatitis A and $\mathrm{E}$ seroprevalence in Thailand. PLoS One. 2015;10(4):e0126184.

4. Krain LJ. Hepatitis E Virus in the Terai of Nepal: Community-Based Cohort Study of Pregnant Women in Sarlahi District and Investigation of the 2014 Outbreak in Biratnagar, Morang District: Johns Hopkins University; 2016.

5. Traore KA, Rouamba H, Nébié Y, Sanou M, Traore AS, Barro N, et al. Seroprevalence of fecal-oral transmitted hepatitis A and E virus antibodies in Burkina Faso. PloS one. 2012;7(10):e48125.

6. Yazbek S, Kreidieh K, Ramia S. Hepatitis E virus in the countries of the Middle East and North Africa region: an awareness of an infectious threat to blood safety. Infection. 2016;44(1):11-22.

7. Costa-Mattioli M, Cristina J, Romero H, Perez-Bercof R, Casane D, Colina R, et al. Molecular evolution of hepatitis A virus: a new classification based on the complete VP1 protein. Journal of virology. 2002;76(18):9516-25.

8. Salman M, Ul ZM, Asif N. Hepatitis E outbreak in the province of Punjab, Pakistan: a call for action. Infectious diseases (London, England). 2019;51(8):633-4.

9. Siegl G. Hepatitis A and E enterically transmitted virus infections of the liver. Therapeutische Umschau Revue therapeutique. 2004;61(8):481-6. 


\section{A Cross Sectional Study to Evaluate Awareness About Hepatitis A \& E Among Students in Lahore}

10. Gossner C, Severi E. Three simultaneous, food-borne, multi-country outbreaks of hepatitis A virus infection reported in EPIS-FWD in 2013: what does it mean for the European Union? Eurosurveillance. 2014;19(43):20941.

11. Cui F, Hadler SC, Zheng H, Wang F, Zhenhua W, Yuansheng $\mathrm{H}$, et al. Hepatitis A surveillance and vaccine use in China from 1990 through 2007. Journal of epidemiology. 2009;19(4):189-95.

12. Bosan A, Qureshi H, Bile KM, Ahmad I, Hafiz R. A review of hepatitis viral infections in Pakistan. JPMAJournal of the Pakistan Medical Association. 2010;60(12):1045.

13. Iaconelli M, Purpari G, Della Libera S, Petricca S, Guercio A, Ciccaglione A, et al. Hepatitis A and E viruses in wastewaters, in river waters, and in bivalve molluscs in Italy. Food and Environmental Virology. 2015;7(4):316-24.

14. Zhang J, Zhang X-F, Huang S-J, Wu T, Hu Y-M, Wang $\mathrm{Z}-\mathrm{Z}$, et al. Long-term efficacy of a hepatitis $\mathrm{E}$ vaccine. New England Journal of Medicine. 2015;372(10):914-22.

15. Jacobsen KH, Wiersma ST. Hepatitis A virus seroprevalence by age and world region, 1990 and 2005. Vaccine. 2010;28(41):6653-7.

16. Butt AS, Sharif F. Viral hepatitis in pakistan: past, present, and future. Euroasian journal of hepatogastroenterology. 2016;6(1):70.

17. Pourpongporn $\mathrm{P}$, Samransurp $\mathrm{K}$, Rojanasang $\mathrm{P}$, Wiwattanakul S, Srisurapanon S. The prevalence of antihepatitis $\mathrm{E}$ in occupational risk groups. Journal of the
Medical Association of Thailand $=$ Chotmaihet Thangphaet. 2009;92:S38-42.

18. Ishida S, Yoshizumi S, Ikeda T, Miyoshi M, Goto A, Matsubayashi K, et al. Detection and molecular characterization of hepatitis E virus in clinical, environmental and putative animal sources. Archives of virology. 2012;157(12):2363-8.

19. Butt AS. Epidemiology of viral hepatitis and liver diseases in Pakistan. Euroasian journal of hepatogastroenterology. 2015;5(1):43.

20. Kmush B, Wierzba T, Krain L, Nelson K, Labrique AB, editors. Epidemiology of hepatitis $\mathrm{E}$ in low-and middleincome countries of Asia and Africa. Seminars in liver disease; 2013: Thieme Medical Publishers.

21. Salman M, Ul ZM, Asif N. Hepatitis E outbreak in the province of Punjab, Pakistan: a call for action. Infectious diseases (London, England). 2019:1-2.

22. Shah DK, Jha RK, Ansari S, Sah P, Dhungana GP, Basnet $\mathrm{S}$. Knowledge and awareness regarding hepatitis $\mathrm{B}$ among preclinical medical and dental students of Chitwan Medical College Nepal: a questionnaire-based study. International Journal of Medical Science and Public Health. 2016;5(11):1.

23. Leung C, Wong W, Chan K, Lai L, Luk Y, Lai J, et al. Public awareness of hepatitis B infection: a populationbased telephone survey in Hong Kong. Hong Kong Med J. 2010;16(6):463-9.

24. Ahmed N, Rizvi A, Naeem A, Saleem W, Ahmed A, Parveen S, et al. COVID-19 and public awareness. The Professional Medical Journal. 2020;27(08):1710-6. 